\title{
Stem Cells and Androgen Receptor in Human Periapical Periodontitis
}

\author{
Células Madre y Receptor de Andrógenos en Periodontitis Periapical Humana
}

\author{
"Rodríguez, H.; **Espinoza-Navarro, O.; ***Peñafiel, C.; ****Escobar, E.; "Silva, I.; \\ "Quiroz, P.; *Arriaza, C.; ***** Castro, M. E.; *Sánchez, C.; *Arias, M. \& *** Michea, A.
}

RODRÍGUEZ, H.; ESPINOZA-NAVARRO, O; PEÑAFIEL, C.; ESCOBAR, E.; SILVA, I.; QUIROZ, P.; ARRIAZA, C.; CASTRO, M. E.; SÁNCHEZ, C.; ARIAS, M. \& MICHEA, A. Stem cells and androgen receptor in human periapical periodontitis. Int. J. Morphol., 29(3):947-953, 2011.

SUMMARY: Activation of macrophages in periapical granulomas occurs through the presence of cytokines, endotoxin and other genetic and epigenetic factors, allowing the initiation of inflammation and bone resorption. The present study aims to analyze the presence of CD133 protein (marker of stem cells) and the AR (androgen receptor) protein in biopsies of human odontogenic periapical granuloma. Biopsies from 14 adult male patients with diagnosis of periapical granuloma included in paraffin blocks were processed histologically to obtain 5- $\mu \mathrm{m}$ thick sections. Protein presence was detected and analyzed by immunohistochemistry of CD133 and AR. The quantification considered the number of positive cells in $0.17 \mathrm{~mm} 2$ random areas under the microscope using a $1000 \mathrm{X}$ objective. Both CD133 and AR proteins are expressed abundantly in cells in pathological periapical granulomas tissue. The number of cells expressing CD133 and AR shows a wide variation coefficient, so its variation is a particular feature for each individual. We concluded that in human odontogenic periapical granuloma there are abundant stem cells and cells expressing AR that may be important for the pathogenic inflammatory process.

KEY WORDS: Stem cell; Androgen receptor; Granuloma; Periodontitis.

\section{INTRODUCTION}

The chronic inflammatory periapical odontogenic lesion is the most common pathology found in relation to the alveolar bone of the jaw (Love \& Firth, 2009). It can be classified as chronic periapical periodontitis (periapical granuloma), radicular cyst, and as scar tissue. The most frequent is the periapical granuloma, constituted by a mass of chronic inflammatory tissue, in which isolated nests of epithelium can be found (García et al., 2007).

The periosteum, the thin covering of bones primarily made of connective tissue, is important in bone development and defense against the invasion of inflammatory components in case of injury; this defense mechanism, known as the periosteal reaction, may vary in response to the magnitude, cellularity and biochemistry of the inflammatory process. The periosteal response is associated with the magnitude of the initial damage and inflammation
(Matsumoto et al., 1987). Both inner and outer layers of the periosteum are physiologically important in case of injuries because they may act both as a source of osteocompetent cells as well as a barrier against the infiltration of epithelial cells into the healing site (Carrillo et al., 2008).

Granulomas have been cited as a common factor that may affect the outcome of root canal treatments (Ramachandran Nair et al., 1996; Sjögren et al., 1997). Even when the root canal is correctly cleaned and filled, it is possible that periapical periodontitis will persist, most times asymptomatically. This is due to the high complexity of the root canal system, with accessory canals, ramifications and anastomoses (Perrini \& Castagnola, 1998). Therefore, the periapical granuloma is the most common periapical lesion of endodontic origin (Ramachandran Nair, 2003). Several authors have shown that sexual hormone

*Immunohistochemistry Unit, School of Medicine Universidad de Chile, Santiago, Chile.

** Department of Biological Sciences, Universidad de Tarapacá, Arica, Chile.

${ }^{* * *}$ School of Dentistry, Universidad de Chile, Santiago, Chile.

*****Universidad de Playa Ancha, Valparaíso, Chile. 
receptors have an important role in dental physiology (Mamalis et al., 2011). The findings suggest that testosterone and dihydrotestosterone, acting on the periodontium, may play an important anabolic role in connective tissue and bone repair processes. In cases of chronic inflammatory periodontal disease, when anabolic activity in affected tissues is considerably reduced, the effects of testosterone would be of maximal importance (Daltaban et al., 2006). Studies evaluating the methylation status of cytokine genes may have relevance for inflammatory diseases in which the expression of some cytokines is altered, such as periodontitis (Andia et al., 2010).

In granulomata, cell and tissue development are permanently active processes. In this consideration, this research aims to investigate the presence of stem cells and cells expressing the androgen receptor in periapical granulomas, considering both variables as trophic factors in human chronically inflamed tissues.

\section{MATERIAL AND METHOD}

Biopsies were collected from patients who consulted in the Clinical Care Unit from the School of Dentistry, Universidad de Chile. All samples were obtained and primarily processed by the Referral Institute for Oral Pathology of the same institution.

Biopsies were obtained from 14 adult male patients with clinical diagnosis of periapical granulomas by surgical extraction and alveolar curettage. Collected tissues were fixed in $10 \%$ formalin and processed for routine histological techniques, i.e. paraffin inclusion $\left(56\right.$ to $\left.58^{\circ} \mathrm{C}\right)$, microtome (Microm, Germany) sectioning into $5-\mu \mathrm{m}$ thick slices (in triplicate per patient), and mounting on silanized slides ((3Aminopropyl)triethoxy-silane, Sigma-Aldrich, USA.). Biopsies were analyzed as routine support for the clinical diagnosis and the approbation of the Ethics Committee of the School of Dentistry, Universidad de Chile (Referral Institute for Oral Pathology, IREPO).

A set of histological samples were stained with conventional hematoxylin and eosin stains for morphometrical analysis. Others tissue sections were used for specific immunohistochemical techniques for detection and recognition of specific markers of stem cells (CD133, C24B9, Cell Signaling 3663S, LabVision Co, USA) and androgen receptor (AR, RB9030 rabbit polyclonal antibody, Thermo Fisher Scientific, UK); antigen retrieval was performed with citrate buffer $\mathrm{pH} 6.0$ and $0.1 \mathrm{mM}$ in a conventional steamer (which reaches $98^{\circ} \mathrm{C}$ in less than 30 seconds) during 20 minutes, and immunodetection was revealed by HRP/DAB (BSB003, BioSB, USA). Quantification of CD133+ and AR+ cells considered the number of positive brown cells/0.17 mm2 (1000x); acquired data was collected using Microsoft Excel (2007, Microsoft Corp., USA), and statistical analysis (comparison of means by Student's t-test and Pearson's correlation test) was performed using the InStat software (v2007, GraphPad Co., USA) considering $p \leq 0.05$ for statistical significance. Results were pictured in bar graphs constructed using the means and standard deviations per individual for each immunohistochemical detection.

Digital image capture of immunohistochemical results was carried on using an Olympus CX31 microscope and a 5-Mpx Micrometrics digital camera (Arquimed, Chile). All images were stored in JPGE format.

\section{RESULTS}

The microscopic analyses of all recruited biopsies of patients reconfirmed the initial clinical diagnosis of periapical granuloma, as the characteristic signals of a chronic inflammatory process were observed. In the inflammatory process developed during the formation of human odontogenic periapical granulomas, a confluence of all inflammatory elements of the connective tissue was commonly observed; a reorganization of thick collagen fibers in different directions appearing as irregular dense connective tissue with a typical vascular and cellular elements was detected, as well as a great variety of cell shapes with different cell nuclear organization. A marked lymphocytic infiltrate irregularly distributed in the tissue with a clear cytoplasmic predominance was noticed, and cells were identified as plasma cells or plasmocytes (Fig. 1). These plasma cells were detected by their characteristically eccentric nucleus with centrally distributed heterochromatin and multiple peripheral fragments.

Figures 1 and 2A show the results of the specific immunohistochemical reaction for the demonstration of stem cells by detection of the protein CD133 (cells with brown cytoplasm using HRP/DAB, Figures 1 and 3). Stem cells are usually observed distributed within the network of connective tissue and newly formed small vessels. However, independent of the location of stem cells, their quantification was a single variable depending only on how long the inflammatory process takes to develop, and showed a coefficient of variation relatively stable and low (Fig. 2A).

Similarly, Figures 2B and 3 show the qualitative and 

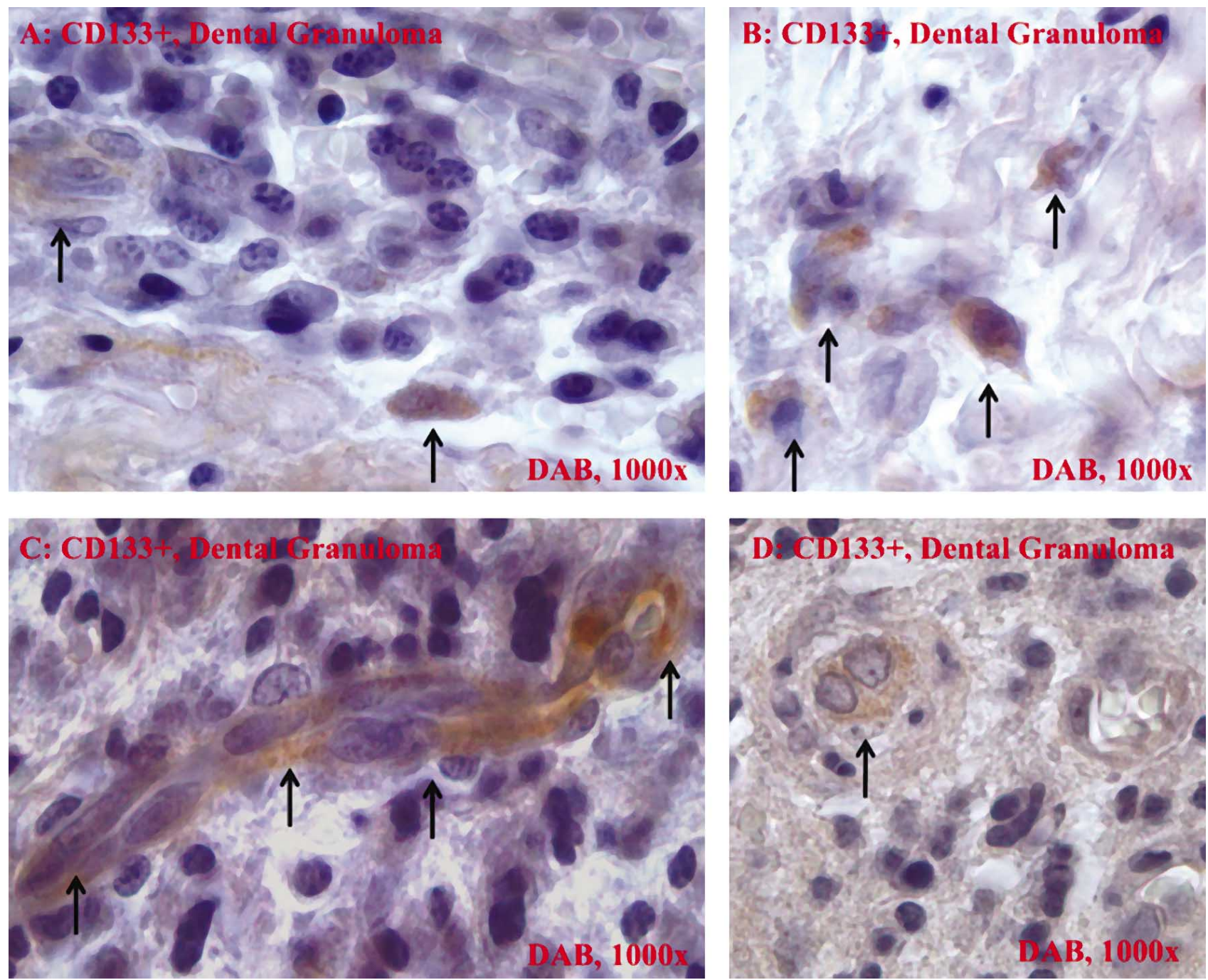

Fig. 1. Presence and distribution of stem cells in biopsies of human odontogenic periapical granulomas: immunodetection of CD133 protein, unique for the plasma membrane of stem cells (arrows). Photomicrographs A and B show the presence of CD133+ cells in the connective stroma; in B and C, cells are CD133+ progenitors for endothelial cells of blood vessels (arrows).

quantitative analysis of positive cells for androgen receptor (AR). Figure 3 shows the immunohistochemical detection of AR+ cells distributed within the connective tissue, while Figure 2B shows AR+ cell quantification; the number of cells positive for the androgen receptor depends on the inflammatory status of the odontogenic periapical granuloma and it is likely this number would increase depending also on the duration of the inflammatory process. It is typically a variable with a large coefficient of variation.

The analysis of a statistical correlation between both variables per patient showed that they have a relative association, probably depending on the individual's physiology, the duration of the pathological condition or the stage of the disease at the time of surgery (Fig. 4).

\section{DISCUSSION}

Inflammation is a highly complex cellular surveillance system that is essential for anti-microbial defense and wound healing. Many host cells including leukocytes, fibroblasts, endothelial cells and epithelial cells are involved in the inflammatory process (Glaros et al., 2009; Menezes et al., 2011).

In teeth, an inflammatory lesion usually extends into the alveolar process and elicits a response, often before evidence of crestal resorption or connective tissue attachment loss has occurred. Deep penetrations of inflammatory cells (as seen on Fig. 1A) into the alveolar bone, periodontal ligament and 


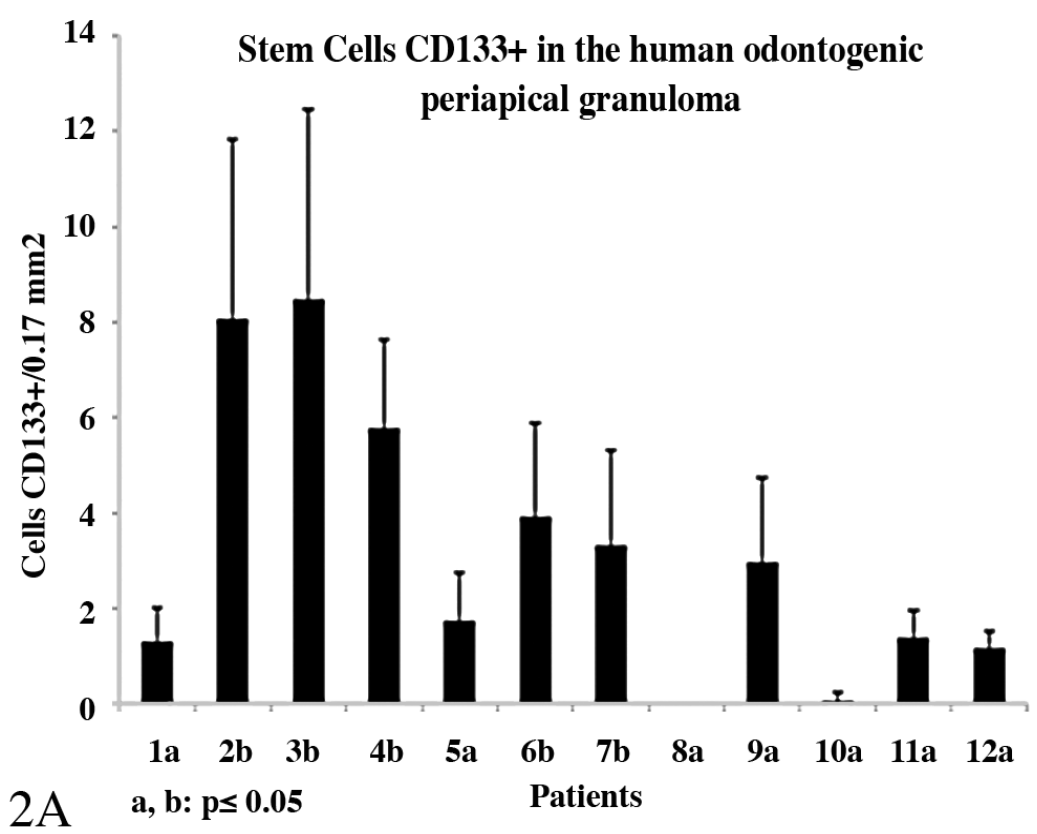

Fig. 2A. Quantification of stem cells in biopsies of human odontogenic periapical granulomas: detection of CD133 protein, unique for the plasma membrane of the stem cells. The bar graph is constructed with the mean and standard deviation of the microscopic assessment for each patient's biopsy in a total of 25 areas of $0.17 \mathrm{~mm} 2$ taken randomly.

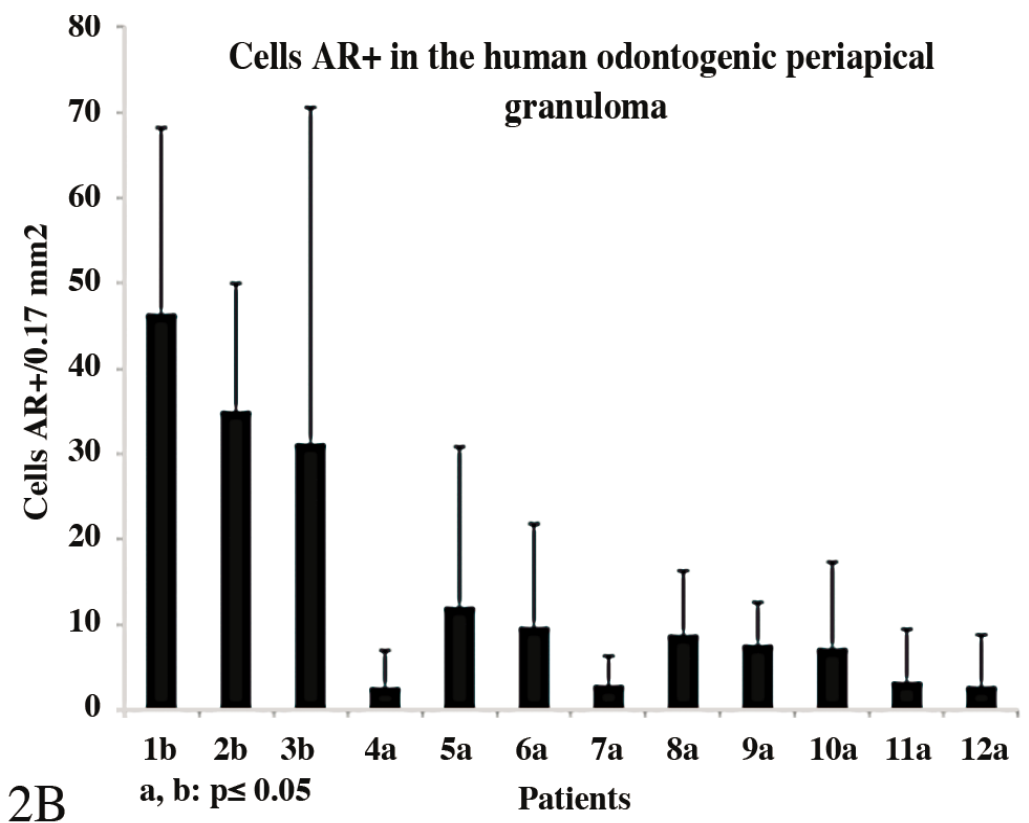

Fig. 2B. Quantification of androgen-dependent cells in biopsies of odontogenic human periapical granuloma: AR protein detection. The bar graph is constructed with the mean and standard deviation of the microscopic assessment of each patient's biopsy in a total of 25 areas of $0.17 \mathrm{~mm} 2$ randomly.

periapical tissues, along with fibrosis and enlargement of the marrow spaces, were common findings in the advanced state of the disease. But their pattern of distribution varies greatly among individuals (Moskow \& Polson, 1991).
The process of wound repair in mammals is complex and is influenced by numerous factors, such as cytokines, chemokines and sexual hormones (Mamalis et al.). Recent studies have shown details about the activity of stem cells in the mesenchyme, and during this process stromal stem cells appear to be positioned to perform functions similar to those of blastemal cells, including communication with the inflammatory cells in the mesenchyme (Stappenbeck \& Miyoshi, 2009). Similar contents are viewed in Figure 1 of the present study, where it is also possible to observe plasmocites (plasma cells) and stem cells in the same areas in biopsies with diagnosis of granuloma.

Numerous molecules play a critical role in inflammation: TNF, IL-1, IL-6, chemokines, Cox-2, LOX-5, MMP's, VEGF, TWIST and cell surface adhesion molecules (Aggarwal \& Gehlot, 2009). However, NFkappa B is common to all these molecules. NF-kappa B has also been linked with the survival of stem cells, early progenitor cells that have acquired self-renewal potential control and with the expression of gene products linked with angiogenesis (Zhou \& Zhang, 2008). Stem cells in stroma and perivascular distribution in inflammatory areas from periapical granuloma are shown in Figures 1 and 2A. AC133+ (similar to CD133) progenitor cells may participate in neovascularization by differentiating into endothelial cells (Richardson et al., 2004; Allegra et al., 2009).

However, the release of cytokines due to inflammatory events activates resident stem (progenitor) cells, or inflammatory cells or pulp fibroblasts that undergo a phenotypic conversion into osteoblast/odontoblast-like progenitors implicated in reparative dentin formation. Activation of antigen-presenting dendritic cells by mild inflammatory processes may also promote osteoblast/odontoblast-like differentiation and expression of extra cellular matrix molecules implicated in mineralization and causes an inflammatory reaction similar to the rest of the neighboring teeth. 


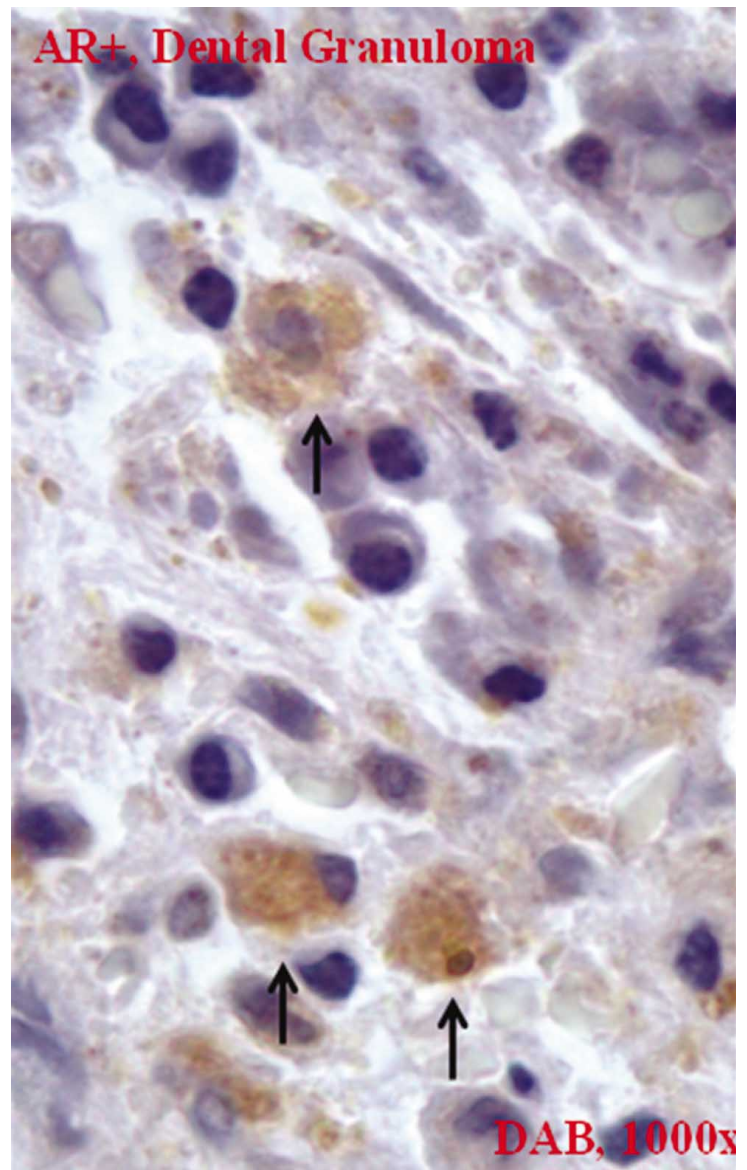

Fig. 3. Presence and distribution of the androgen receptor in cells in biopsies of odontogenic human periapical granuloma: immunodetection of the AR (androgen receptor) protein (arrows). Photomicrographs show the presence of AR+ cells in the connective stroma.

On the other hand, observational and interventional studies suggest that testosterone ( $\mathrm{T}$ ) supplementation reduces inflammatory markers in both young and old hypogonadal men. Close relationship exists between the development of a pro-inflammatory state and the decline in $\mathrm{T}$ levels and that changes in inflammatory markers and $\mathrm{T}$ in aging men are causally linked (Maggio et al., 2005).

An age-associated decline in $\mathrm{T}$ levels and an increase in proinflammatory cytokines contribute to chronic diseases in older men. Soluble IL-6 receptor (sIL-6r) is significantly and inversely correlated with total T and bioavailable T (Maggio et al., 2006).

The androgen receptor (AR) is expressed by inflammatory cells, keratinocytes and fibroblasts during wound healing, suggesting that androgens may regulate inflammatory and/or repair processes (Gilliver et al., 2003). This AR picture in the inflammatory tissue and cells are shown in Figures 2B, 3 and 4.

It is possible that androgens require the transforming growth factor beta signaling intermediate Smad3 to be present in order to

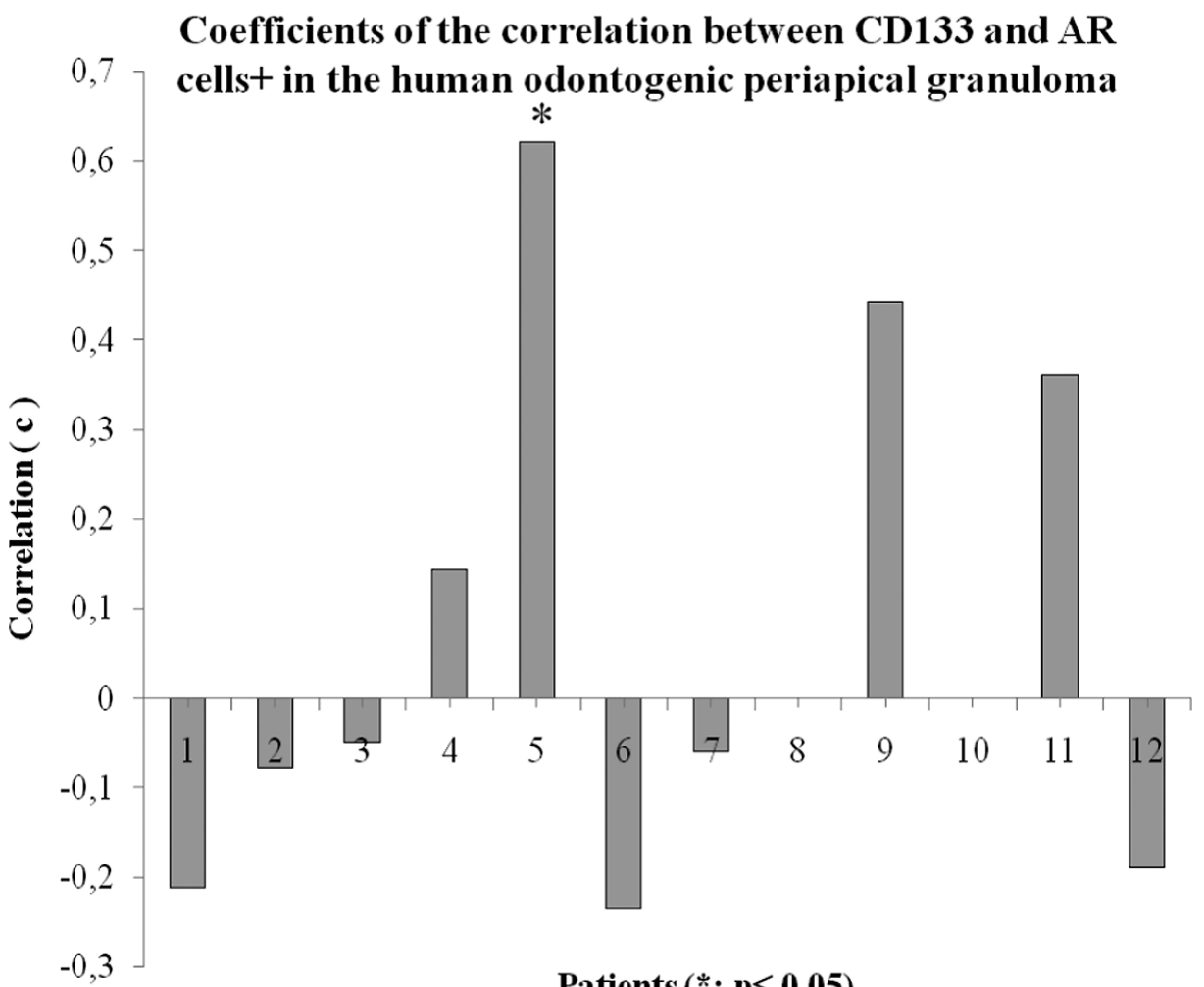

Fig. 4. Pearson's correlation analysis between the numbers of CD133+ and AR+ cells for each individual biopsy.

Patients $(*: p \leq 0.05)$ 
RODRÍGUEZ, H.; ESPINOZA-NAVARRO, O; PEÑAfIEL, C.; ESCOBAR, E.; SILVA, I.; QUIROZ, P.; ARRIAZA, C.; CASTRO, M. E.; SÁNCHEZ, C.; ARIAS, M. \& MICHEA, A. Stem cells and androgen receptor in human periapical periodontitis. Int. J. Morphol., 29(3):947-953, 2011

influence repair and local pro-inflammatory cytokine levels (Andia et al.). That reducing 5-a-dihydrotestosterone levels through 5-a-reductase antagonism markedly accelerates healing suggests a specific target for future therapeutic intervention in impaired wound healing states in elderly males (Gilliver et al., 2006; Li, 2011).

In this study, we demonstrate that in the human periapical odontogenic granuloma there is an inflammatory reaction with stem cells and androgen-responsive cells. We conclude that during the development of chronic human periapical odontogenic granulomata, the presence of stem cells, infiltration of inflammatory cells, and androgen receptor expression must play an important role and these cellular and molecular aspects must be relevant for the development of new therapeutic strategies.

\section{ACKNOWLEDGMENTS}

The authors would like to express their thankfulness to Mr. Juan Borja for his role as Technical Assistant of the Laboratory of Immunohistochemistry; Programme of Morphology, School of Medicine, Universidad de Chile. This research was supported by Universidad de Tarapacá through Major Project $\mathrm{N}^{\circ} 4710-11$ and was partially supported by FONDECYT grant $\mathrm{N}^{\circ} 1101046$.

RODRÍGUEZ, H.; ESPINOZA-NAVARRO, O; PEÑAFIEL, C.; ESCOBAR, E.; SILVA, I.; QUIROZ, P.; ARRIAZA, C.; CASTRO, M. E.; SÁNCHEZ, C.; ARIAS, M. \& MICHEA, A. Células madre y receptor de andrógenos en periodontitis periapical humana. Int. J. Morphol., 29(3):947-953, 2011.

RESUMEN: La activación de los macrófagos en los granulomas periapicales humanos se producen a través de la presencia de citoquinas, endotoxinas y otros factores genéticos y epigenéticos que permiten la iniciación de la inflamación y la reabsorción ósea. El presente estudio pretende analizar la presencia de proteína CD133 (marcador de células madre) y de la proteína RA (receptor de andrógenos) en las biopsias de granulomas periapicales odontogénicos humanos. Las biopsias de 14 pacientes varones adultos con diagnóstico de granuloma periapical fueron incluidos en bloques de parafina y se procesaron histológicamente para obtener secciones de 5 micras de espesor. La presencia de CD133 y RA fueron detectadas y analizadas por inmunohistoquímica. La cuantificación se realizó considerando el número de células positivas en áreas al azar de $0,17 \mathrm{~mm} 2$, utilizando microscopio con objetivo de $1000 \mathrm{X}$. Ambas proteínas, CD133 y RA se expresan en abundancia en las células del tejido patológico con granuloma periapical. El número de células que expresan CD133 y RA presentan un amplio coeficiente de variación, por lo que su variación es una característica particular de cada individuo. Se concluye que en granuloma periapical odontogénico humano se expresan abundantes células madre y proteínas receptoras de andrógenos, antecedentes que pueden ser muy importantes en la expresión y diagnosis de los procesos patológicos inflamatorios.

PALABRAS CLAVE: Células madre; Receptor de andrógenos; Granulomas; Periodontitis.

\section{REFERENCES}

Aggarwal, B. B. \& Gehlot, P. Inflammation and cancer: how friendly is the relationship for cancer patients? Curr. Opin. Pharmacol., 9(4):351-69, 2009.

Allegra, A.; Coppolino, G.; Bolignano, D.; Giacobbe, M. S.; Alonci, A.; D'Angelo, A.; Bellomo, G.; Teti, D.; Loddo, S.; Musolino, C. \& Buemi, M. Endothelial progenitor cells: pathogenetic role and therapeutic perspectives. J. Nephrol., 22(4):463-75, 2009.

Andia, D. C.; de Oliveira, N. F.; Casarin, R. C.; Casati, M. Z.; Line, S. R. \& de Souza, A. P. DNA methylation status of the IL8 gene promoter in aggressive periodontitis. J. Periodontol., 81(9):1336-41, 2010.

Carrillo, C.; Peñarrocha, M.; Bagán, J. V. \& Vera, F. Relationship between histological diagnosis and evolution of 70 periapical lesions at 12 months, treated by periapical surgery. J. Oral Maxillofac. Surg., 66(8):1606-9, 2008.

Daltaban, O.; Saygun, I. \& Bolu, E. Periodontal status in men with hypergonadotropic hypogonadism: effects of testosterone deficiency. J. Periodontol., 77(7):117983, 2006.

García, C. C.; Sempere, F. V.; Diago, M. P. \& Bowen, E. M. The post-endodontic periapical lesion: histologic and etiopathogenic aspects. Med. Oral Patol. Oral Cir. Bucal, 12(8):E585-90, 2007.

Gilliver, S. C.; Ashworth, J. J.; Mills, S. J.; Hardman, M. J. \& Ashcroft, G. S. Androgens modulate the inflammatory response during acute wound healing. J. Cell Sci., 119(Pt 4):722-32, 2006. 
Gilliver, S. C.; Wu, F. \& Ashcroft, G. S. Regulatory roles of androgens in cutaneous wound healing. Thromb. Haemost., 90(6):978-85, 2003.

Glaros, T.; Larsen, M. \& Li, L. Macrophages and fibroblasts during inflammation, tissue damage and organ injury. Front. Biosci., 14:3988-93, 2009.

Li, T. J. The odontogenic keratocyst: a cyst, or a cystic neoplasm? J. Dent. Res., 90(2):133-42, 2011.

Love, R. M. \& Firth, N.Histopathological profile of surgically removed persistent periapical radiolucent lesions of endodontic origin. Int. Endod. J., 42(3):198202, 2009.

Maggio, M.; Basaria, S.; Ble, A.; Lauretani, F.; Bandinelli, S.; Ceda, G. P.; Valenti, G.; Ling, S. M. \& Ferrucci, L. Correlation between testosterone and the inflammatory marker soluble interleukin-6 receptor in older men. $J$. Clin. Endocrinol. Metab., 91(1):345-7, 2006.

Maggio, M.; Basaria, S.; Ceda, G. P.; Ble, A.; Ling, S. M.; Bandinelli, S.; Valenti, G. \& Ferrucci, L. The relationship between testosterone and molecular markers of inflammation in older men. J. Endocrinol. Invest., 28(11 Suppl Proceedings):116-9, 2005.

Mamalis, A.; Markopoulou, C.; Lagou, A. \& Vrotsos, I. Oestrogen regulates proliferation, osteoblastic differentiation, collagen synthesis and periostin gene expression in human periodontal ligament cells through oestrogen receptor beta. Arch. Oral Biol., 56(5):446$55,2011$.

Matsumoto, T.; Nagai, T.; Ida, K.; Ito, M.; Kawai, Y.; Horiba, N.; Sato, R. \& Nakamura, H. Factors affecting successful prognosis of root canal treatment. J. Endod., 13(5):239-42, 1987.

Menezes, R.; Bramante, C. M.; da Silva Paiva, K. B.; Letra, A.; Carneiro, E.; Fernando Zambuzzi, W. \& Granjeiro, J. M. Receptor activator NFkappaB-ligand and osteoprotegerin protein expression in human periapical cysts and granulomas. Oral Surg. Oral Med. Oral Pathol. Oral Radiol. Endod., 102(3):404-9, 2006.

Moskow, B. S. \& Polson, A. M. Histologic studies on the extension of the inflammatory infiltrate in human periodontitis. J. Clin. Periodontol., 18(7):534-42, 1991.

Perrini, N. \& Castagnola, L. W. Hess \& O. Keller's Anatomical Plates: Studies on the Anatomical Structure of Root Canals in Human Dentition by a Method of Making the Tooth Substance Transparent (1928). Milano, Lainate, 1998.

Ramachandran Nair, P. N. Non-microbial etiology: foreign body reaction maintaining post-treatment apical periodontitis. Endod. Topics, 6:114-34, 2003.

Ramachandran Nair, P. N.; Pajarola, G. \& Schroeder, H. E. Types and incidence of human periapical lesions obtained with extracted teeth. Oral Surg. Oral Med. Oral Pathol. Oral Radiol. Endod., 81(1):93-102, 1996.

Richardson, G. D.; Robson, C. N.; Lang, S. H.; Neal, D. E.; Maitland, N. J. \& Collins, A. T. CD133, a novel marker for human prostatic epithelial stem cells. J. Cell Sci., 117(Pt 16):3539-45, 2004.

Sjögren, U.; Figdor, D.; Persson, S. \& Sundqvist, G. Influence of infection at the time of root filling on the outcome of endodontic treatment of teeth with apical periodontitis. Int. Endod. J., 30(5):297-306, 1997.

Stappenbeck, T. S. \& Miyoshi, H. The role of stromal stem cells in tissue regeneration and wound repair. Science, 324(5935):1666-9, 2009.

Zhou, J. \& Zhang, Y. Cancer stem cells: Models, mechanisms and implications for improved treatment. Cell Cycle, 7(10):1360-70, 2008.

\section{Correspondence to:}

Prof. Dr. Héctor Rodriguez.

Unidad de Histoembriología

Facultad de Medicina, Universidad de Chile.

Av. Independencia 1027

ZIP 8389100

Santiago

CHILE

Phone: 5629786267

Fax: 5629786264.

Email: hrodrigu@med.uchile.cl

Received: 01-06-2011

Accepted: 28-06-2011 